\title{
2011年東北地方太平洋沖地震津波の被災地における 斜め視空中写真判読による建物被害のマッピング
}

\author{
Mapping of Building Damage using Oblique Aerial Photos \\ in the A.ected Areas of the 2011 Tohoku Earthquake Tsunami
}

\author{
郷右近英臣 ${ }^{1} \cdot$ 越村俊 ${ }^{2}$ \\ Hideomi GOKON and Shunichi KOSHIMURA
}

\begin{abstract}
In order to develop a method to evaluate building damage in the tsunami a.ected area in a quantitative manner, the authors conducted visual damage inspection using an oblique aerial photos in Wakabayashi-ward in Miyagi Prefecture. As the result of damage inspection, building damage were classi.ed into six classes to identify the damage distribution in Wakabayashi-ward and the validity of this method was demonstrated to comprehend the impact in the aftermath of the disaster.
\end{abstract}

\section{1. 序論}

2011 年 3 月 11 日, 東北地方太平洋沖でMw9.0の地震が 発生した。本地震に伴い発生した津波は東北地方沿岸全 域に波及し，死者・行方不明者 18,879 人，全壊建物 129,885棟という激甚な被害をもたらした（2012年5月 16 日，警察庁)。災害発生直後に，広域におよぶ建物被害 の空間分布を迅速かつ定量的に把握するには，リモート センシングによる建物被害判読が有効である。しかし， 直上より撮影された航空写真等の画像（直下視画像）で は建物側面部の被害を判読することは不可能であり, 詳 細な被害程度の把握には限界がある。

これらの課題に対し, 斜め視空中写真を用いた建物被 害判読は有用である。長谷川ら（2001）は，兵庫県南部 地震の被災地に扔いて空撮ハイビジョン映像を用いるこ とにより，建物被害の目視判読を実施した。そして建物 被害を,「倒壊」,「大破」,「中波」,「小破」,「軽微」, 「被害なし」の6段階に分類することにより，地震被災地 において斜め視空中写真による建物被害把握手法の有効 性を実証した。

しかし，地震のみによる被害を受けた地域と比較して， 津波による被害を受けた地域では津波漂流物や瓦礫の散 乱，津波堆積物の有無等により，被害の様相は大きく異 なる。それゆえ長谷川ら（2001）の被害判読基準をその まま津波被災地に適用することは難しく，津波被災地に おいても，斜め視空中写真の優位性を生かした新しい建 物被害評価手法を確立する必要がある。そこで本研究で は，2011年東北地方太平洋沖地震津波の事例を通じて， 国土地理院と株式会社パスコにより撮影されたへリコプ

1 学生会員 修(工) 東北大学大学院工学研究科

2 正会員博 (工) 東北大学教授 災害科学国際研究所

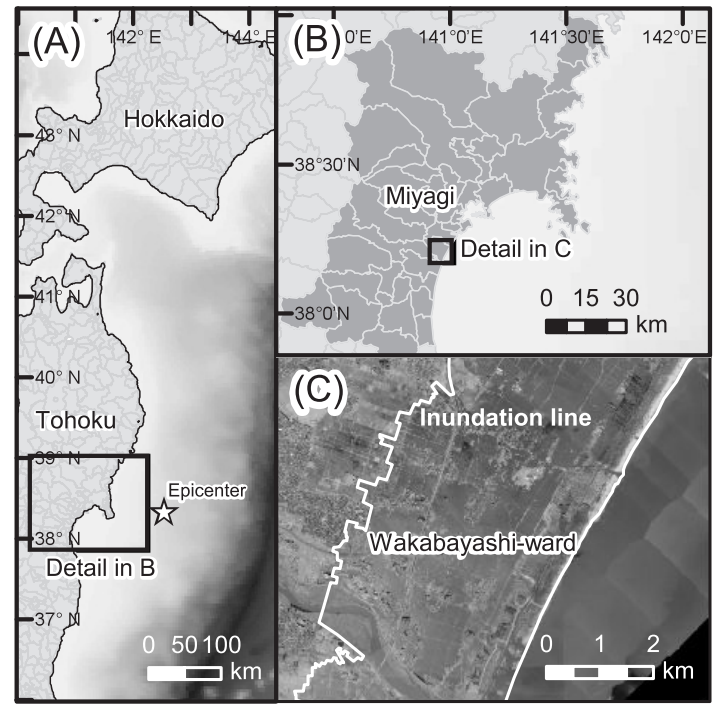

図-1 本研究の対象領域（宮城県仙台市若林区）

ターからの斜め視空中写真を使用することにより，建物 被害を定量的かつ網羅的に評価するための手法を開発す ることを目的とする.

\section{2. 研究手法}

\section{(1) 対象領域}

本研究の対象領域は，津波により激甚な被害を受けた 宮城県仙台市若林区である（図-1），若林区は仙台平野に 位置し, 海岸線から数キロに渡り平坦な地形が続く。海 岸線から打よそ $3 \mathrm{~km}$ の地点には仙台東部道路が南北に走 り，東部道路から海側には震災前まで田園地带と民家が 広がっていた。津波来襲時には東部道路基礎部の盛土に より，遡上する津波がせき止められ，道路を挟んで海側 では建物流失のような甚大な被害が集中したものの，陸 
表-1＼cjkstart斜め視空中写真による建物被害分類基準

\begin{tabular}{l|l}
\hline 分類項目 & 判読基準 \\
Washed-away & 直下視航空写真の目視判読により屋根が残存していないことを確認した建物 \\
Major & 直下視航空写真判読では「残存」と判定されたが, 建物の柱や梁に被害が生じ, 構造体に被害が及んでいる建物 \\
Moderate & 航空写真判読では「残存」と判定され, 柱や梁などの構造体は残存しているが, 壁の大部分が破壊された建物 \\
Slight & 航空写真判読では「残存」と判定され, 柱や梁などの構造は残存しているが, 壁の一部が破壊された建物 \\
Flooded & 浸水は認められるが, 構造や壁等に被害は見られない \\
\hline
\end{tabular}

側では津波による被害は軽微に抑えられた。本研究では, 道路から海側の被害が集中した領域を対象とする。

\section{(2) 解析手順}

まず，震災前後に撮影された国土地理院のオルソ化さ れた航空写真（国土地理院，2011a）とゼンリン電子地 図を GIS 上で統合表示し, 被災前後の建物の位置合わせ を行う.そして, 株式会社パスコや国土地理院が公開し ている津波浸水域の情報から, 津波により浸水被害を受 けた建物を抽出する（株式会社パスコ, 2011 ; 国土地理 院，2011b). 次に, 直下視の航空写真を用いて建物屋根 の「有り・無し」に着目し，目視による「流失建物」の 被害判読を実施する (図-2). その際, 判読結果は建物 GIS データの属性に付与していく. 詳細な建物被害判読 のために, 斜め視空中写真（国土地理院, 株式会社パス コ撮影）に含まれる GPS 情報から撮影位置データを作成 し (図-3), 空中写真・ゼンリン電子地図と同一空間表示 する. 最後に若林区の津波浸水域内建物 5,072棟を対象 とし，目視により建物被害を5段階に分類する. 分類は 図-4, 表-1の基準に基づき実施し，建物が全て津波によ り流失した場合には「Washed away」，建物は残存したも のの梁や柱のような主要構造部に被害が及んだ場合には $\lceil$ Major」, 柱や梁のような主要構造には被害が及んでい ないものの壁の大部分が被害を受けた場合には「 Moderate」,柱や梁のような主要構造部は残存したものの 壁の一部が破壊された場合には「Slight」,浸水したもの の特に外傷がみられない場合には「Flooded」と分類する. さらに建物構造を, 目視により「Wood (木造)」, 「Steel (鉄骨造)」,「RC」,「その他 (Other)」の4種類に分類す る.ただし, 本研究では被災前の若林区を網羅的に捉え た斜め視空中写真を取得できなかったことや，3章で後 述する様々な外的要因により判読困難であった構造物は 判定不可（N/A）と分類した.

\section{（3）被災地を捉えた航空写真・斜め視空中写真}

2011 年 3 月 11 日の震災直後, 福島県の一部を除く東北 地方全域において国土地理院により緊急航空写真撮影が 行われた。以上の緊急時対応により得られた航空写真は 高い分解能を有し (空間分解能 $80 \mathrm{~cm}$ ), 地表の被害状況 を克明に捉えている. それらの航空写真のうち, 本研究 では, 流失建物の被害判読に, 2011年3月 12 日に若林区
表-2 斜め視空中写真による建物被害判読結果

\begin{tabular}{l|c|c|c|c|c|c}
\hline & Wood & Steel & RC & Other & N/A & Total \\
\hline Washed away & 0 & 0 & 0 & 0 & 2270 & 2270 \\
Major & 84 & 11 & 4 & 0 & 0 & 99 \\
Moderate & 222 & 29 & 12 & 0 & 1 & 264 \\
Slight & 305 & 47 & 12 & 1 & 7 & 372 \\
Flooded & 1581 & 333 & 37 & 39 & 13 & 2003 \\
N/A & 0 & 0 & 0 & 0 & 64 & 64 \\
\hline Total & 2192 & 420 & 65 & 40 & 2355 & 5072 \\
\hline
\end{tabular}

を捉えた航空写真を使用した。

建物側面部の被害判読には，株式会社パスコにより 2011 年 3 月 29 日から 4 月 7 日に撮影された斜め視空中写 真と, 国土地理院により 2011 年 5 月 18 日，25日に撮影さ れた斜め視空中写真を使用した. 両者の斜め視空中写真 の撮影時期は一ヶ月以上異なるため, 3 月末の時点では 残存していた建物も，5月の時点では一部撤去されてい た.このように画像の撮影時期により判読結果に相違が 出た場合には, 先に撮影が行われた方の斜め視空中写真 を利用して，判定を実施した。

\section{3. 斜め視空中写真を用いた建物被害判読}

\section{（1）判読結果とその精度}

仙台市若林区の浸水域内建物 5,072 棟に対し, 斜め視 空中写真を用いて，表-1の基準に基づき建物側面部を含 めた詳細な被害把握を実施し, 被害を5段階に分類した. さらに，建物の外観より構造種類を「Wood（木造）」, $\lceil$ Steel (鉄骨造) 」, 「RC」,「Other (その他)」の4種類へ 分類した. 以上の解析により得られた建物被害判読およ び建物構造分類の空間分布を図-5および表-2に示す. 図5 (左図) は建物被害の空間分布, 図-5 (右図) は建物構 造種類の空間分布を示している. 直下視・斜め視空中写 真による建物被害判読の結果, 海岸線から $1.5 \mathrm{~km}$ 以内の 建物のほとんどが流失し，さらに $1.5 〜 2.5 \mathrm{~km}$ の地点にお いても多くの建物が何らかの外傷を受けたことが確認さ れた. また，建物構造種類の空間分布を明らかにする事 により，浸水域内の広い範囲に津波に弱い木造建物が分 布していることが判明し, 木造建物の脆弱性が改めて確 認された. 

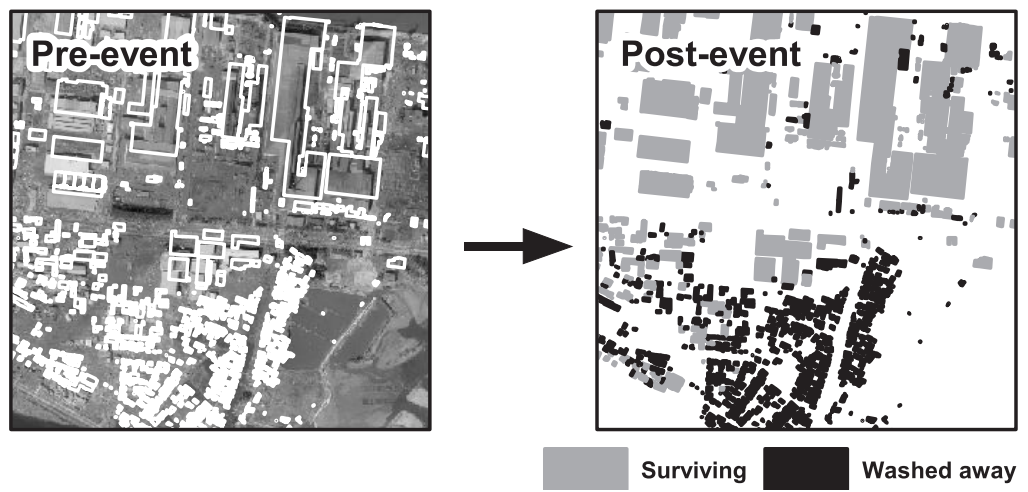

図-2＼cjkstart直下視の空中写真の判読による流失建物被害分類例

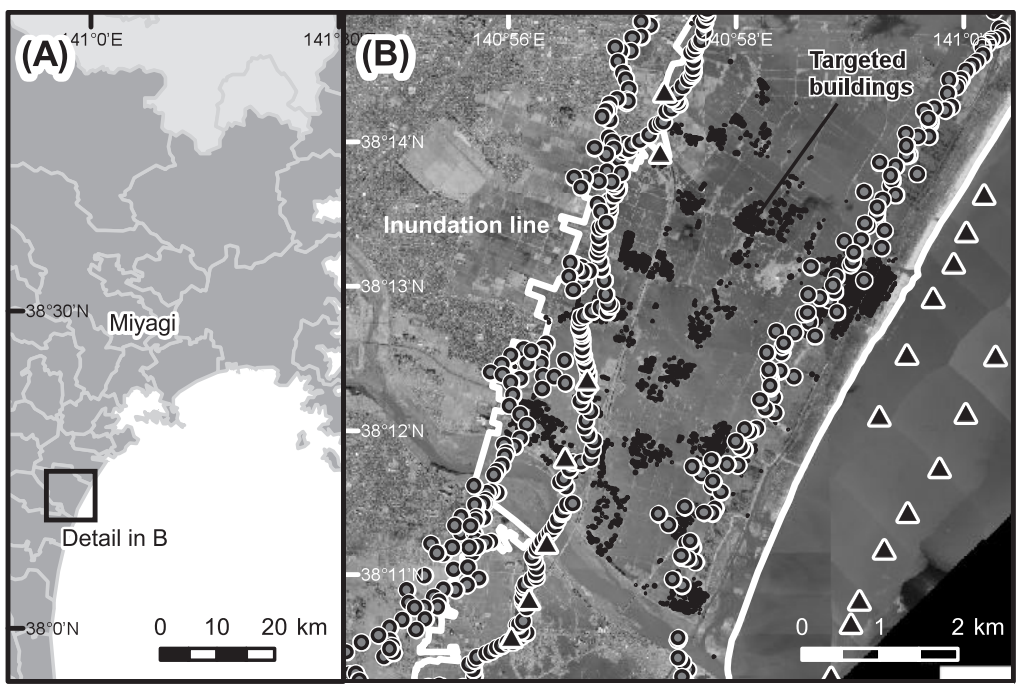

図-3 斜め視空中写真の撮影地点

表-2より，直下視の空中写真から判読した流失建物 2,2 70 棟に加え，直下視では「残存」と判定された建物 2,802 棟のうち，実際には26\%の建物が軽微な外傷を含む何ら かの被害（Major,Moderate,Slight）を受けていた事がわか った.一方, 主要構造部に被害が及んだ建物（Major）は, 残存建物 2,802 棟のうち $4 \%$ と，それほど多くない事もわ かった. 次に建物構造種類の分類を実施し, 建物被害と 構造種類の棟数の比較したところ, 残存建物の $80 \%$ 程度 が木造建物であることがわかった．また，鉄骨造や RC造 の建物も，直下視では「残存」と判定された建物のうち 24\%が何らかの被害を受けた事がわかった。

直下視衛星画像・航空写真を用いた判読では，屋根の 形状変化に表れない建物側面部の被害判読が不可能であ り，直上からは建物被害を実被害と比較して過小評価す るという点がこれまでの課題であった。越村ら（2010） は，2009年サモア地震津波被災地において，被災前後の 津波被災地を捉えた高分解能のQuickBird衛星画像の目
視による建物被害判読を実施し，GroundTruthデータとの 比較を行った。そして, 衛星画像判読により残存（流失 以外）と判定された建物 75 棟のうち，15棟（20\%）が何 らかの被害を受けたという調査結果を示した。越村ら （2010）の調査結果を本研究と比較すると, 分類基準や 分類条件, 津波の来襲状況等が異なるものの, 本研究で 明らかにした残存建物 2738 棟に対する何らかの被害を受 けた建物 735 棟 $(26.8 \%)$ の割合と近い值を取っており, 直下視航空写真・衛星画像において残存と判定された津 波浸水域内の建物のうち，目安として $20 \sim 30 \%$ 程度の被 害を考慮すべきであることがわかった。

以下では，斜め視空中写真による建物被害判読の限 界・課題について考察を行う.

（2）建物の遮蔽による判読限界

建物密集地域や植生が建物周囲に生い茂っている場 合，写真上で判読対象とする建物が手前の植生や建物に 遮蔽されることにより, 判読が困難となる事がある。図- 


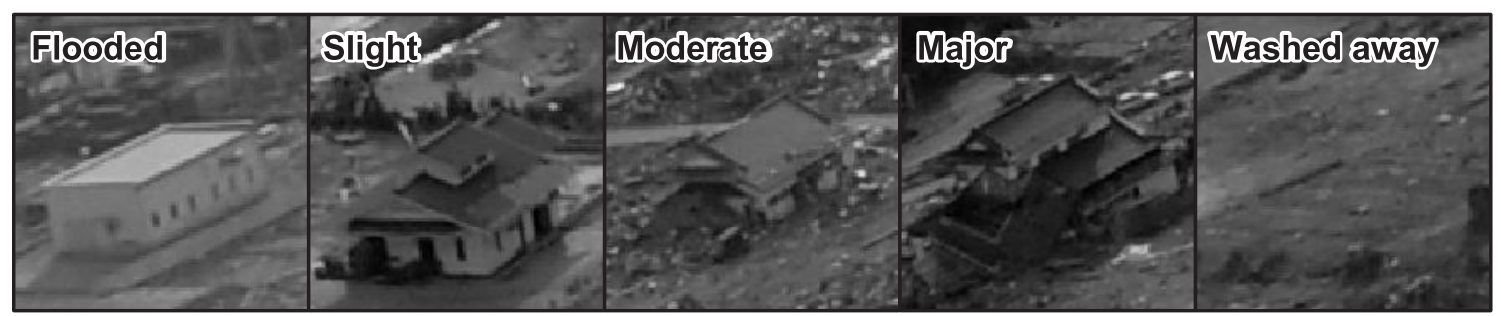

図-4 斜め視空中写真による建物被害分類例
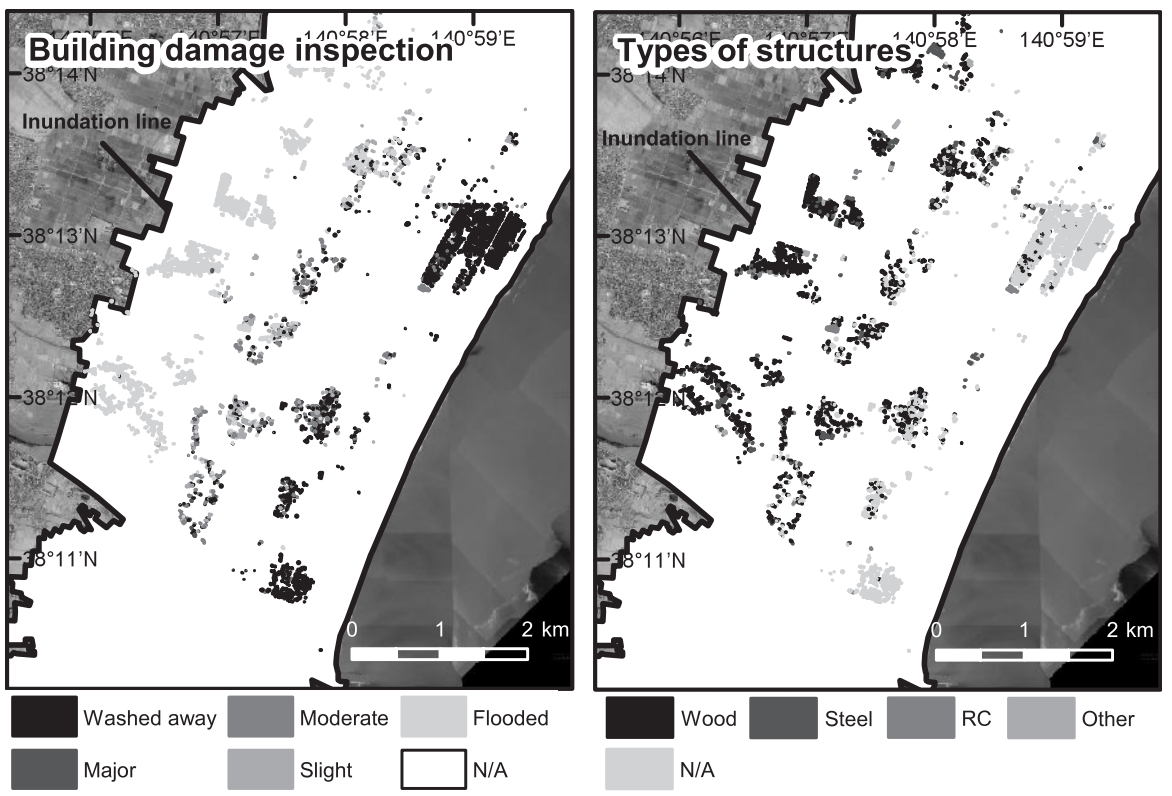

図-5 斜め視空中写真による建物被害判読結果

6 (A) のように手前の建物が後ろの建物を遮蔽した場合 や，図-6（B）のように植生が対象とする建物を遮蔽する 場合は, 建物側面部の被害を把握することは難しい。こ のような場合, 斜め視空中写真を用いた建物側面部の判 読を実施するよりも, 直下視航空写真を用いることによ り，屋根の形状変化に着目した被害判読を実施すべきで ある。

\section{（3）遠方において解像度が粗くなる例}

斜め方向からの撮影に伴い, 同一写真でも見かけの解 像度が大きく異なるため, 写真上で手前に位置する建物 の判読は容易であるが, 遠方の建物は判読が困難となる. 図-6 (C) に示したように撮影写真遠方においては, 写真 の解像度が落ちるだけでなくエアロゾルのような微粒子 がカメラと対象物の間に存在する事により，被害判読が 困難となる。一方, 図-6(A) のように撮影地点からの距 離が短く解像度が高い場所では, 建物の梁や柱, 空ガラ スの破損など詳細に被害を把握することが可能である.

(4) 撮影方向による判読限界

図-3のように，多くの斜め視空中写真は津波被災地の
建物を海側と陸側の二方向から挟むように撮影される. 海岸線からまっすぐ入射する津波と, 海岸線にまっすぐ 引いて行く方向に関しては被害を把握できるが，実際に は津波は建物に対し四方八方から押し寄せてくるため, 撮影方向以外の建物側面部の被害を把握できない。その 結果，判読結果には誤差が含まれることが予想される.

（5）判読時間の制約

本研究では, 若林区の浸水域内建物 5,072 棟のうち, 判読におよそ3 週間を要した. 著者が以前, 直下視航空 写真の目視による流失建物の判読を宮城県浸水域内建物 162,015 棟に対し実施した際も 3 週間を要したことと比較 すると, 斜め視空中写真の目視による建物被害判読は, 直下視航空写真の目視判読と比較して, 多くの作業時間 を要する事がわかった. その原因として, 直下視衛星画 像や航空写真の判読とは異なり, GIS 上で建物ポリゴン と斜め視空中写真上の建物を重ね合わせる事ができず, 斜め視空中写真上で被害判定した建物と, GIS上で表示 されている建物の同定に, 技術と時間を要したためと考 えられる。 


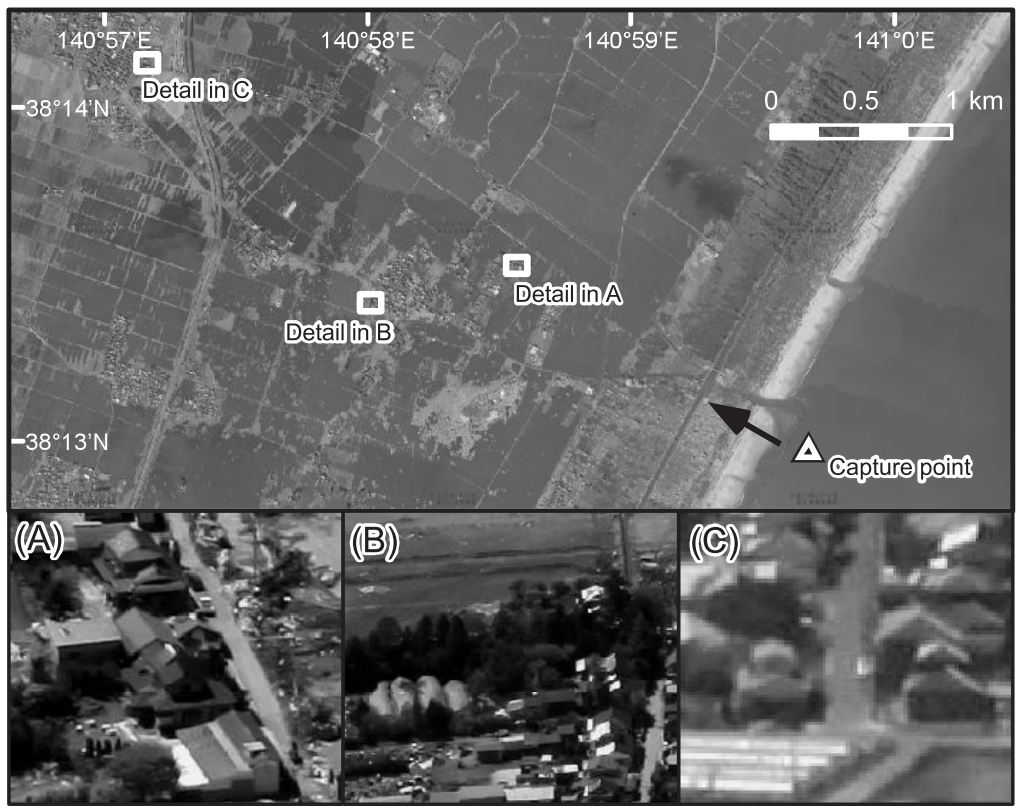

図-6 斜め視空中写真判読の際に生じる問題の例（（A）建物が他の建物を遮蔽する例，（B）植生等が遮蔽物となる例，（C）遠方に おいて解像度が粗くなる例）

\section{4. 結論}

本研究では, 2011 年東北地方太平洋沖地震津波被災地 において，直下視の航空写真と斜め視空中写真を用いて 建物被害の目視判読を実施し，被害程度を5段階に分類 した。そして，津波被災地における建物側面部を含めた 被害の網羅的な把握手法を提案するとともに，建物被害 の空間分布を明らかにした。さらに，建物の外観よりそ の構造種類の判別も実施し, 建物構造と被害との関係に ついて考察した. 最後に, 斜め視空中写真を用いた建物 被害判読手法の抱える課題について整理した.

本研究における主要な結論を以下に列挙する. 直下視 の判読では「被害なし」と判定された建物のうち, 実際 には26.8\%の建物が何らかの被害を受けていたことがわ かった。ささに, 構造種類と被害状況を比較・検討する ことにより, 残存建物のうち $80 \%$ 程度が木造建物である 事がわかり，本来津波に強いとされる鉄骨造や RC 造の 建物も，残存建物のうち実際には24\%程度が壁面や構造 体に何らかの被害を受けた事がわかった．以上の斜め視 空中写真を用いた解析により，広域津波災害の発生直後 に, 直下視・斜め視の空中写真を網羅的に取得できれば, 迅速な被害把握に活用できることを実証した。また，斜 め視空中写真による建物被害判読手法の限界について, 検討を実施した。 その結果, 判読対象とする建物が何ら かの要因により遮蔽される場合や，遠方において写真の 解像度が粗くなること, 撮影方向が限定されることによ
り判読が困難になることがあり，また判読に要する時間 も課題であることがわかった.

謝辞 : 本研究の一部は東北大学災害科学国際研究所プロ ジェクト経費および科学研究費補助金（課題番号： 22681025，24651195）の補助を受けて実施された。解析 に用いた空中写真の一部は株式会社パスコから提供頂い た.ここに記して謝意を表する。

\section{参 考 文 献}

株式会社パスコ（2011）：平成23年（2011年）東日本大震災に 関する情報（オンライン）, http://www.pasco.co.jp/disaster info/110311/，参照2011-04-05

警察庁 (2012)：被害状況と警察措置（オンライン）, http://w ww.npa.go.jp/archive/keibi/biki/index.htm，参照 20-12-05-16

国土地理院（2011a）：平成23年（2011年）東北地方太平洋沖 地震正射画像デー夕 (オルソ画像), http://saigai.gsi.go.jp /h23t-aiheiyo-zort/index.html

国土地理院（2011b）：2万 $5 千$ 分 1 浸水範囲概況図（オンライ ン), http://www.gsi.go.jp/kikaku/kikaku40014.html, 参照 2011-05-31

越村俊一 - 哌右近英臣 - 行谷佑一 - 西村裕一 - 中村有吾 Gerard Fryer - Akapo Akapo - Laura Kong (2010)：数值解 析・GIS 分析・衛星画像解析の統合による津波被災地探 索技術 -2009 年サモア諸島沖地震津波災害における実 践と検証一, 土木学会論文集 B2（海岸工学論文集，第 57 巻), Vol.66, No.1, pp.1361-1365.

長谷川弘忠・山崎文雄・松岡昌志（2001）：空撮ハイビジョン 映像を用いた兵庫県南部地震による建物被害の目視判読, 土木学会論文集, No.682/I-56, pp.257-265. 